\title{
European patent for PCR enzyme clouded by Russian claim
}

London. A Russian scientist whose research group was one of the first to isolate a thermostable enzyme from the bacterium Thermus aquaticus is claiming that his enzyme is identical to the widely used Taq DNA polymerase for which the US biotechnology company Cetus Corporation subsequently received a US patent.

Stanislav Gorodetsky, now head of the laboratory of molecular genetics at the Institute of Gene Biology in Moscow, says that the figure of 60,000 daltons identified as the enzyme's molecular weight in the original paper describing its purification was a "misprint". The printed figure has been used by Cetus to back its claim that the two enzymes are different; the corrected figure, says Gorodetsky, suggests they are identical.

Gorodetsky's claim adds a new twist to the bid by the Swiss-owned pharmaceutical company Hoffman-La Roche to secure European patent rights on Taq polymerase. The enzyme is used worldwide in the polymerase chain reaction (PCR) process, for which Roche bought the patent rights (including the rights to Taq polymerase) from Cetus in 1991 for $\$ 300$ million; it is currently marketed for PCR use exclusively through Perkin-Elmer Corporation, and has annual sales estimated last year at \$25 million in Europe alone.

The patent on Taq polymerase has been controversial, partly because the enzyme is still seen by many scientists as a "natural" product. Thomas Gold, for example, the microbiologist who originally discovered the bacterium during a visit to hot springs in Yellowstone Park in 1965, says he considers the organism to be in the public domain.

But arguments about the equitability of the Taq patent cut little ice with patent offices, since their concern has been primarily on questions of novelty and usefulness. The main focus of disagreement has been whether Cetus was justified in claiming that its scientists were first to purify the enzyme, given the acknowledged existence of previous reports - particularly that published by Gorodetsky and his colleagues, based on the work of postgraduate student A. Kaledin (Biokhimiya 45, 644-651; April 1980).

Kary Mullis, the inventor of PCR, has admitted that it was the Russian paper that first gave him the idea of using a polymerase obtained from the T. aquaticus bacterium as the thermostable enzyme needed for continuous re-use in the successive heating and cooling steps that amplify DNA fragments. (The previous enzyme, Klenow polymerase, had to be replenished after every step.)

Despite the Russian publication, Cetus was able to persuade the US Patent Office of the novelty of its own Taq, purified from the bacterium by researchers David Gelfand and Susannah Stoffel; the US patent was awarded in December 1989. But last summer, an examiner at the European Patent Office in Munich, issuing a preliminary response to a patent application from Roche, gave the opinion that the Russian paper contradicted the novelty of the claims being made by Roche, since it appeared to refer to the same enzyme.

Roche has challenged this interpretation. In a revised patent submission, filed at the end of February, Roche defends its claim by saying that several technical features of the enzyme described in the Russian paper are different from those in its own submission. In particular, Roche points out that the molecular weight of the Russian enzyme, measured by two separate techniques, was described by Gorodetsky and his colleagues as being either 62,000 or 60,000 daltons. The enzyme purified by Cetus has a molecular weight of 86,000 to 90,000 daltons.

However Gorodetsky has explained that the figure of 60,000 , based on a comparison of the effects of centrifugation of polymerase sediments with those of bovine serum albu$\min$, is a misprint. The actual value calculated, he says, was about 80,000 - much closer to the Cetus figure.

Referring to the alternative estimate of 62,000 daltons, obtained using electrophoresis on a polyacrylamide gel, Gorodetsky says that its accuracy is questionable, as the polymerase and the markers used for comparison were put in different tubes.

The impact of Gorodetsky's claims will be limited by the fact that no correction was published (a follow-up paper by the same authors was rejected by another publication). Moreover, Roche still has a significant claim to the rights on its genetically engineered recombinant Taq polymerase.

As well as confusing the European patent application, the Russian claim, if con- firmed, could strengthen the hand of the US biochemical supply company Promega Corporation, which is challenging the US patent in New Jersey courts (see Nature 362, 686 ; 1993) - a move widely seen as the company's reaction to a suit filed against it by Roche alleging infringement of a licensing agreement between the companies.

Randall Dimond, chief technology officer at Promega, says the company's own scientists have shown that the Gorodetsky and Cetus enzymes may be identical, and that the Russian paper contains "an error in the understanding of molecular weight".

Despite the continuing controversy, Roche says it is confident that its revised patent submission now meets all the novelty and inventiveness requirements of the European Patent Convention. It has pointed out, for example, that the difference in published molecular weights was not the only reason that Cetus believed it had purified a separate enzyme; other factors include a higher level of activity, and a greater ability to maintain this ability in moving from an alkali to an acidic environment.

Claude Montandon, Roche's director of licensing and new technology assessment, says the company is optimistic that it will be allowed the Taq patent "in the near future". He adds that, together with Perkin-Elmer, Roche is in the process of fine-tuning a licensing policy covering its DNA polymerase enzymes, although it is not at present prepared to provide any further details.

Meanwhile, Gorodetsky says that the Russian team's discovery was not patented when the enzyme was isolated in 1978 because the only way of doing so at that time would have been through an inventor's certificate — which would have practically ruled out the possibility of publishing the data. "We felt that it was more important to bring the results to public notice," he says.

David Dickson

\section{Brain drain smaller than feared}

Moscow. Only a few thousand researchers have left Russia permanently since the dissolution of the Soviet Union, according to a new report by the Russian Academy of Sciences. Although that represents less than 1 per cent of the estimated scientific work force, it does not measure the quality of those who have emigrated.

The academy, in an annual report by its analytic centre, paints a dismal picture of the future of Russian science and says that hope for an improved economic situation has all but vanished. But it also criticizes the government and the scientific community for failing to adopt reforms that could improve conditions in the short term, including setting priorities among various disciplines to make the best use of scarce resources.

The study says that not even the current request before the Russian Parliament for 673 billion rubles for science is likely to help without "the introduction of non-traditional methods and means of financing science". The report also emphasizes the role of international contributions.

Vladimir Pokrovsky 